\title{
Detection Trend of Helminth Eggs in the Strata Soil Samples from Ancient Historic Places of Korea
}

\author{
Min Seo ${ }^{1 *}$, Jong-Yil Chai ${ }^{2,3}$, Myeung Ju Kim4, Sang Yuk Shim ${ }^{5}$ Ho Chul Ki ${ }^{6}$, Dong Hoon Shin ${ }^{7, *}$ \\ 'Department of Parasitology and Research Center for Mummy, College of Medicine, Dankook University, Cheonan 31116, Korea; '2Department of \\ Parasitology and Tropical Medicine, Seoul National University College of Medicine, Seoul 03080, Korea; ${ }^{3}$ Institute of Parasitic Diseases, Korea \\ Association of Health Promotion, Seoul 07653, Korea; ${ }^{4}$ Department of Anatomy, Dankook University, Cheonan 31116, Korea; ${ }^{5}$ Buyeo Cultural \\ Heritage Center, Buyeo-gun, Chungcheongnam-do 33193, Korea; 'Institute of Forensic Medicine, Seoul National University, Seoul 03080, Korea; \\ ${ }^{7}$ Bioanthropology and Paleopathology Laboratory, Department of Anatomy/Institute of Forensic Science, Seoul National University College of \\ Medicine, Seoul 03080, Korea
}

\begin{abstract}
For several years, we have conducted a series of studies on the patterns of ancient parasitism prevailing in the soil of rural and urban areas of past Kingdom of Korea. Actually, during our survey of paleoparasitology in archaeological sites of Korean peninsula, numerous ancient parasite eggs were discovered in the samples from the city districts of Hansung (Joseon) and Buyeo (Baikje), the palace moat at Gyeongju (Silla), shell-midden site at Bonghwang-dong (Silla to Joseon), and the reservoir found in Hwawangsansung fortress (Silla). By the paleoparasitological studies, with respect to parasitism in the high-density populations of ancient towns and cities, we have managed to catch glimpses of the patterns prevalent therein: a serious parasitic contamination of the soil in ancient urban areas, but not in rural areas of the past. Our historical research also proposed the plausible mechanism of parasite infection very serious indeed among urban populations in Korean history. Although city dwelling doubtless has accrued significant benefits for people and populations with agriculture, it can be equally supposed that living in such highly populated areas might have facilitated the spread of parasite infection.
\end{abstract}

Key words: Paleoparasitology, parasite egg, urban, strata soil sample, Korea

\section{INTRODUCTION}

From the perspective of parasitology, increases both in population density and the filth might have led to the soil contamination by parasite eggs in permanent settlements [1-4]. Indeed, parasite infections must have been common among the concentrated populations of more sedentary agricultural societies [5]. However, corroborative reports to date have been surprisingly rare due to difficulties in historical or scientific studies on this subject.

Paleoparasitology, which entails the analysis of ancient samples by modern parasitological techniques, is thus a powerful investigative tool in the study of parasite infections in human history. It is the study of parasites found in ancient archaeological remains and on that basis, the tracing of the history of

\footnotetext{
- Received 22 May 2016, revised 3 August 2016, accepted 4 October 2016.

*Corresponding authors (bbbenji@naver.com; cuteminjae@gmail.com)

(C) 2016, Korean Society for Parasitology and Tropical Medicine

This is an Open Access article distributed under the terms of the Creative Commons Attribution Non-Commercial License (http://creativecommons.org/licenses/by-nc/4.0) which permits unrestricted non-commercial use, distribution, and reproduction in any medium, provided the original work is properly cited.
}

host-parasite relationships [6-9]. By the morphological or molecular techniques on the samples obtained at various archaeological sites, scientific clues for consolidating tentative concepts about parasite infections in the history of mankind could have been obtained successfully.

Fortunately, for the past several years, parasitologists have also been provided with invaluable opportunities to conduct examinations on the samples from ancient archaeological ruins of South Korea. By a series of scientific analyses, the characteristics of parasite infections in ancient major cities began to be revealed for the first time ever in this country. Considering that the scientific knowledge is very rarely available about ancient parasite infections in highly populated areas of the past, the present review can be significant to concerned parasitologists who have tried to obtain information about the parasitic infection patterns prevailing among ancient city-dwellers in so much detail. Actually, we found several parasitic eggs from the strata soil in highly populated ancient cities of Korea and analyzed the results according to population density, weather (flood), and environmental factors. 


\section{EXAMINATION OF STRATA SOIL SAMPLES TO DETECT PARASITE EGGS}

Paleoparasitological studies on pre-modern Korean populations have utilized different forms of archaeological evidence, most notably coprolites obtained from Joseon mummies. By comparison of data thus obtained with 20th century National Survey statistics, clearer pictures of parasitic infections in Joseon populations could have been obtained successfully [9].

In order to draw conclusions on parasitism patterns prevailing in historical settlements; however, parasitological examinations have to proceed in a different way. Actually, it is well recognized that soil contamination of parasite eggs is a preliminary factor central to a coherent understanding of soil-transmitted parasitism in history [10-14]. This is clearly based on the concept that soil-transmitted parasite infections even in the 20th century developing countries are usually coincided by heavy parasite-egg contamination of soils [15-18]. We therefore examined strata soil samples from archaeological sites to deduce the parasite infection status among ancient town- or city-dwellers (Fig. 1A). The chronology of each geological stratum could be differentiated by archaeologists' date estimation of the accompanying cultural remains or carbon dating results of the stratum.

For a particular settlement, together with archaeological estimation of their dates, examinations of strata soil samples can reveal the patterns of parasite-egg soil contamination prevailing there for a specific historical period. Whenever we find ancient parasite eggs in significant quantity of soil samples from a certain stratum (Fig. 1B-D), the implication is that many city-
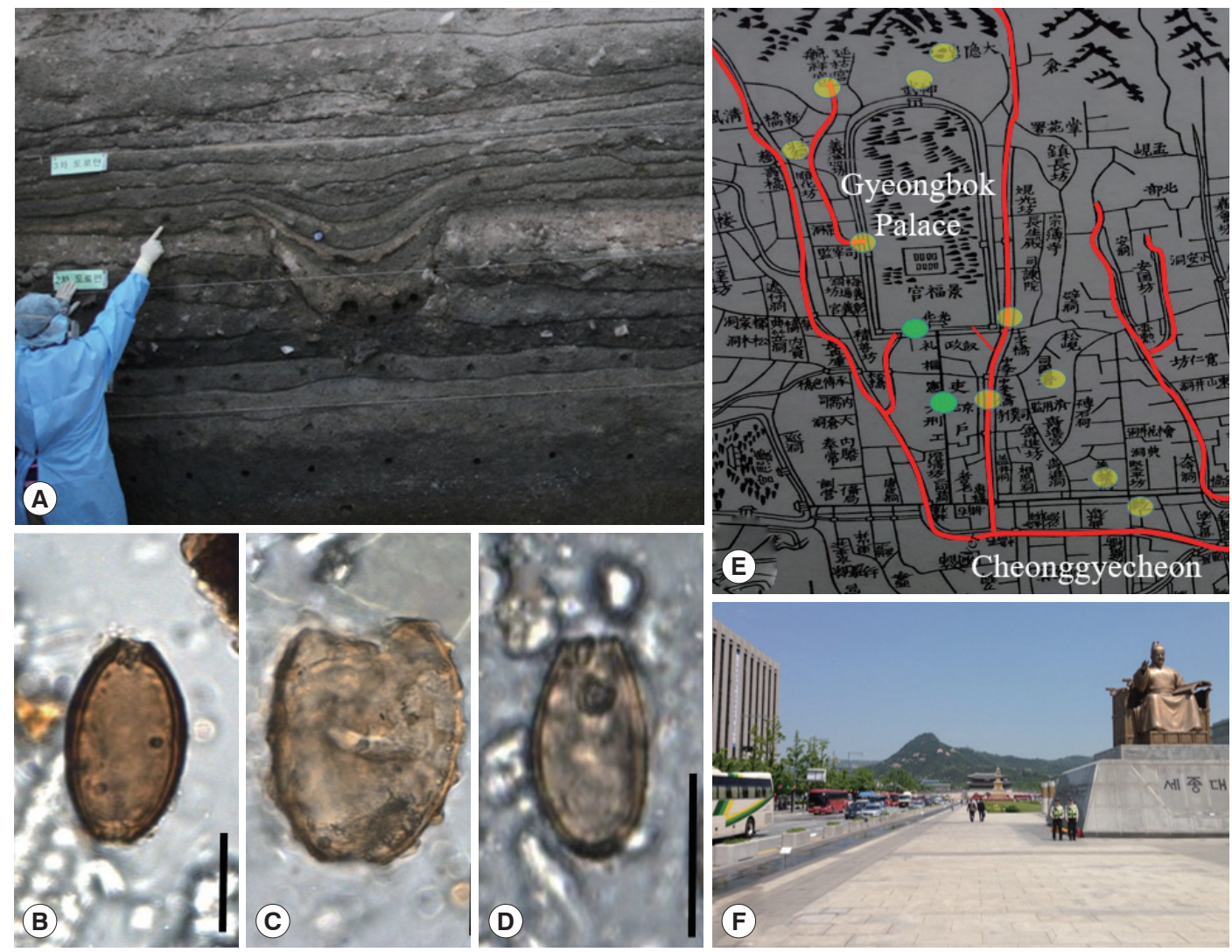

Fig. 1. (A) Paleoparasitological sampling at archaeological site (Yukjo Street, Old Seoul City). The soil sediments from each geological layer represent the soil contamination pattern at specific time period. (B) to (D) Ancient parasite eggs found in the soil strata samples of Yukjo Street. (B) Trichuris trichiura, (C) Ascaris lumbricoides, (D) Clonorchis sinensis. Scale bars $=20 \mu \mathrm{m}$. (E) In historical records of Joseon period, flooding was very common in the Old Seoul City during rainy season. Red line, the watercourse of the stream running through Old Seoul City. Yellow dots represent the places for which we could identify historical evidences for flooding at rainy season. Authors discovered ancient parasite eggs in the main street of Old Seoul City (green dots), one of the busiest areas during Joseon period. The map is Suseonjeondo, the map of the Joseon capital (1846-1849 CE) (F) The same place of green dots today. The region was and still is one of the busiest streets in Korean peninsula. 
dwellers there were highly infected by parasites at that particular moment in history.

The technique by which soil-sediment samples are processed is by now well established [19-21]. Briefly, soil samples are re-hydrated in $0.5 \%$ trisodium phosphate solution for 1 week. They are then filtered through multiple-layered gauze and precipitated for 1 additional day. Once the upper turbid layer is discarded, the precipitates are again dissolved in 10\% neutral buffered formalin and finally, dropped onto slides for light-microscopic examinations. As for any parasite eggs subsequently found, their sizes were measured and their numbers per gram (EPG) of soil and per slide (EPS) were estimated. On the basis of the data thus obtained, conjectures can be made on the parasitic infection situation prevailing among a population of a given settlement.

\section{POPULATION DENSITY AND PARASITISM}

The first insight we obtained from paleoparasitological study on Korean archaeological sites is the close relationship of ancient parasitism to population density. Actually, in our studies of the past several years, we found that the higher the population density within a given area in history, the heavier the contamination of parasitic eggs in strata soil samples by microscopic examinations (Tables 1-3). During our fullfledged survey of paleoparasitology in archaeological sites of Korean peninsula (2010-2012; Project of National Research Institute of Cultural Heritage), numerous ancient parasite eggs were discovered in the samples from ancient major-capital city ruins such as Old Seoul City (Joseon), Buyeo (Baikje), and Gyeongju (Silla). On the other hand, we noted that the presence of ancient parasite eggs was reported very rarely from the samples of rural areas at the same time period (Tables 1-3).

The pattern is much clearly seen in a series of our detailed studies on the archaeological ruins of Buyeo city, the capital of the ancient Baekje kingdom (18 BCE to $660 \mathrm{CE}$ ), and it's nearby rural areas (Gongju, Yeongi, and Cheonan). Although Buyeo city is now only a small town in the southwestern area of the Korean peninsula, during the period of 538 to $660 \mathrm{CE}$, it was a big political and cultural center of the Baekje King-

Table 1. Paleoparasitological Examinations on the Baekje Soil Samples from Buyeo and Its Adjacent Rural Areas

\begin{tabular}{|c|c|c|c|}
\hline Area & Estimated Date & Results & Eggs Per Gram (EPG) \\
\hline Hongsung & Bronze & Negative & ND \\
\hline Yesan & Bronze & Negative & ND \\
\hline Buyeo/Songguk-ri & Bronze/Baekje & Negative & ND \\
\hline Gongju/Tancheon & Proto-Three Kingdom/Baekje & Negative & ND \\
\hline Yeongi/Nasung-ri & 3-4 C CE (Proto-Three Kingdom/Baekje) & Negative & ND \\
\hline Yeongi/Seoksam-ri & 3-4 C CE (Proto-Three Kingdom/Baekje) & Negative & ND \\
\hline Cheonan/Wiryesung & 4-5 C CE (Baekje) & Negative & ND \\
\hline \multirow[t]{4}{*}{ Buyeo/Gatap-ri* } & 5-6 C CE (Baekje) & Ascaris & \\
\hline & & Trichuris & \\
\hline & & Clonorchis & \\
\hline & & Pygidiopsis summa & \\
\hline \multirow[t]{3}{*}{ Buyeo/Gua-ri (319) ${ }^{\star}$} & 6-7 C CE (Baekje) & Ascaris & \\
\hline & & Trichuris & \\
\hline & & Clonorchis & \\
\hline \multirow[t]{2}{*}{ Buyeo/Ssangbuk-ri (314-5)* } & Baekje & Ascaris & 8.6 \\
\hline & & Trichuris & 7.1 \\
\hline \multirow[t]{2}{*}{ Buyeo/Seokmok-ri (143-26) ${ }^{\star}$} & Baekje & Ascaris & 10.0 \\
\hline & & Trichuris & 5.0 \\
\hline \multirow[t]{2}{*}{ Buyeo/Ssangbuk-ri (184-11)* } & Baekje & Ascaris & 0.3 \\
\hline & & Trichuris & 0.4 \\
\hline Buyeo/Gwanbuk-ri (159-1)* & Unified Silla & Negative & ND \\
\hline Buyeo/Dongnam-ri (321-3) ${ }^{\star}$ & Baekje & Negative & ND \\
\hline \multirow[t]{2}{*}{ Buyeo/Gugyo-ri* } & Joseon & Ascaris & \\
\hline & & Trichuris & \\
\hline Buyeo/Gugyo-ri (387-7) ${ }^{\star}$ & Unified Silla/Goryeo & Negative & ND \\
\hline
\end{tabular}

Shaded parts represent the archaeological sites of highly populous cities in history; *Buyeo, the capital city of Baekje kingdom; ND, Not Determined. 
Table 2. Results of paleoparasitological examinations on the samples from archaeological sites of Seoul, Gyeonggi, and Gangwon Provinces

\begin{tabular}{|c|c|c|c|c|c|}
\hline Provinces & Sites & Estimated date & Archaeological findings & Results & Eggs per gram \\
\hline \multirow[t]{18}{*}{ Seoul } & Pungnabtosung & 4-5 C CE (Baekje) & House & Negative & ND \\
\hline & Hansung/Cheongjin-dong ${ }^{a}$ & 15-17 C CE (Joseon) & House/Toilet? & Ascaris & ND \\
\hline & & & & Trichuris & ND \\
\hline & Hansung/Jongmyo-Gwangjang ${ }^{a}$ & Joseon period & House/ & Ascaris & $21.3-161.6$ \\
\hline & & & Streambed/Alley/Alley-Side Gutter & Trichuris & $10.0-135.0$ \\
\hline & $\begin{array}{l}\text { Hansung/Buam-donga } \\
\text { (Baiksokdongcheon) }\end{array}$ & Joseon & House/Toilet? & Ascaris & ND \\
\hline & & & & Trichuris & ND \\
\hline & Hansung/Namsan-dong 1ga ${ }^{a}$ & Joseon-Modern & Toilet? & Ascaris & ND \\
\hline & & & & Trichuris & ND \\
\hline & & & & Diphyllobothrium & ND \\
\hline & Hansung/Royal Palace Wall ${ }^{a}$ & Joseon & $\begin{array}{l}\text { Soil strata underneath or in the vicinity of } \\
\text { Joseon palace wall }\end{array}$ & Ascaris & $37.6-165.2$ \\
\hline & & & & Trichuris & $33.1-90.3$ \\
\hline & Hansung/Yukjo Street ${ }^{a}$ & Joseon & Soil strata of the main street & Ascaris & 13.3 \\
\hline & & & & Trichuris & $16.5-34.8$ \\
\hline & & & & Clonorchis & 17.9 \\
\hline & Hansung/Royal Arsenal ${ }^{\mathrm{a}}$ & Joseon & $\begin{array}{l}\text { Soil samples from stream bed during } \\
\text { Joseon period }\end{array}$ & Ascaris & $23.7-27.1$ \\
\hline & & & & Trichuris & $16.7-44.2$ \\
\hline & & & & Diphyllobothrium & 19.3 \\
\hline \multirow[t]{2}{*}{ Gyeonggi } & Pyeongtaek/Segyo-dong & $\begin{array}{l}\text { Proto-Three Kingdom } \\
\text { Period }\end{array}$ & House & Negative & ND \\
\hline & Paju/Hyeeumwon-ji & Goryeo & Toilet?/Drain & Negative & ND \\
\hline \multirow[t]{2}{*}{ Gangwon } & Youngwol/Jeongan Fortress & Three Kingdom Period & Drain & Negative & ND \\
\hline & Samcheok/Jukseoru & Goryeo to Joseon & House/Drain & Negative & ND \\
\hline
\end{tabular}

ND, Not determined.

aOld Seoul city of Joseon dynasty (Hansung).

dom, surrounded by vast areas of rural provinces. By the excavations of Buyeo's ancient districts, still buried several meters underground, we got ancient strata soil samples, from which the information on parasite infection patterns among the Buyeo people of Baekje period could be obtained [22].

Briefly, in microscopic examinations on the Buyeo soil sediment samples from multiple districts (Gatap-ri, Gua-ri, Ssangbuk-ri, and Seokmok-rk) representing Baekje period, we revealed a numbers of Ascaris, Trichuris, Clonorchis, and Pygidiopsis summa eggs. Meanwhile the strata soil samples from more outlying suburban or rural areas of Baekje kingdom (Gongju, Yeongi, Cheonan) included very few ancient parasite eggs [22] (Table 1). This suggests that parasite infection prevalence might have been different in terms of the areas between the ancient city and its surrounding provincial areas. Parasite-egg contamination patterns during ancient Baekje period might have been closely correlated with population densities at that time because the higher the number of ancient parasite eggs within a given amount of strata soil samples, the heavier the parasitic infection among the people during the same time period [22].

Relative to Buyeo city, the soil contamination in the other ancient highly populated areas such as Old Seoul City (Hansung), the capital of the Joseon Dynasty (1392-1910 CE) $[2,21,23]$, Gyeongju, the capital of ancient Silla kingdom, and a mountaintop fortress Hwawangsansung of Three Kingdom Period [24], was also found to be similarly heavy in our investigations (Tables 2,3).

In the study of the strata samples of Joseon Hansung city, we found a heavy contamination of ancient Trichuris, Ascaris, Clonorchis, and Diphyllobothrium eggs that were originated from samples of streambed, alley, alley-gutter, Royal palace wall, the Yukjo (main) street, and Royal Arsenal ruins, etc. (Table 2). As ancient parasite eggs were rarely discovered in the samples from the rural area ruins of Korean peninsula, the profuse discovery of ancient parasite eggs in Hansung city samples was very exceptional to us. Like Buyeo city, a higher number of ancient parasite eggs within Hansung strata soil could have been 
Table 3. Results of paleoparasitological examinations on the samples from archaeological sites of Gyeongsang, Jeolla, and Jeju Provinces

\begin{tabular}{|c|c|c|c|c|c|}
\hline Provinces & Sites & Estimated date & Archaeological information & Results & Eggs per gram \\
\hline \multirow[t]{14}{*}{ Gyeongsang } & \multirow[t]{3}{*}{ Changnyeong/Hwawangsansung } & \multirow[t]{3}{*}{ Silla } & \multirow[t]{3}{*}{ Reservoir of Fortress } & Ascaris & $3.2-7.0$ \\
\hline & & & & Trichuris & $2.5-5.6$ \\
\hline & & & & Taenia & $0.4-0.5$ \\
\hline & \multirow[t]{3}{*}{ Gimhae/Bonghwang-dong } & \multirow[t]{3}{*}{ Silla to Goryeo } & \multirow[t]{3}{*}{ Shell midden } & Ascaris & $0.8-5.0$ \\
\hline & & & & Trichuris & $0.8-11.6$ \\
\hline & & & & Dicrocoelid & 2.5 \\
\hline & $\begin{array}{l}\text { Gyeongju/Gyeongju National } \\
\text { Museum }\end{array}$ & Silla & ND/Storing place/House & Negative & ND \\
\hline & \multirow[t]{2}{*}{ Gyeongju/Nodong-dong 12} & \multirow[t]{2}{*}{ Silla to Modern } & \multirow[t]{2}{*}{ House } & Ascaris & 0.4 \\
\hline & & & & Trichuris & 0.4 \\
\hline & \multirow[t]{2}{*}{ Gyeongju/Weolseong Palace } & \multirow[t]{2}{*}{ Silla } & \multirow[t]{2}{*}{ Moat } & Ascaris & 0.4 \\
\hline & & & & Trichuris & 100.25 \\
\hline & Pohang/Chogok & Bronze-Three Kingdom Period & Rice Paddy/Farm & Ascaris & 1.6 \\
\hline & Gimhae/Daeseong-dong & Gaya & Tomb/Shell midden & Negative & ND \\
\hline & Uljin/Jukbyeon & Joseon & Toilet? & Negative & ND \\
\hline \multirow[t]{15}{*}{ Jeolla } & Yeosu/Songhyeon-maeul & Bronze & Tomb & Negative & ND \\
\hline & Damyang/Hwabang-ri & Bronze-Three Kingdom Period & Rice Paddy & Negative & ND \\
\hline & Gwangju/Songha-dong & Bronze & Farm & Negative & ND \\
\hline & Naju/Heojin-ri & Goryeo & Kiln/House & Negative & ND \\
\hline & Iksan/Songhak-dong & Proto Three Kingdom Period & ND & Negative & ND \\
\hline & \multirow[t]{3}{*}{ Jangheung/Hyangyang-ri } & \multirow[t]{3}{*}{ Bronze/Joseon } & \multirow[t]{3}{*}{ Tomb/Drain } & Negative (Tomb) & ND \\
\hline & & & & Trichuris (Drain) & 0.2 \\
\hline & & & & Ascaris (Drain) & 0.2 \\
\hline & Jangheung/Yonggang-ri & Iron Age to Goryeo & Tomb/House & Negative & ND \\
\hline & Suncheon/Seongsan-ri & $4-5 \mathrm{C} C \mathrm{C}$ & House & Negative & ND \\
\hline & Naju/Samyeong-dong & Goryeo & Farm & Negative & ND \\
\hline & Naju/Hoejin-ri & Goryeo & House & Negative & ND \\
\hline & Gokseong/Shin-ri & Iron Age & Pit & Negative & ND \\
\hline & Sunchang/Musu & 4-5C CE & House & Negative & ND \\
\hline & Gochang/Hwangsan & Three Kingdom Period & Toilet? & Negative & ND \\
\hline \multirow[t]{6}{*}{ Jeju } & Jeju/Yongdam-2dong & 3C BCE to 4C CE & House & Negative & ND \\
\hline & Jeju/Samyang-2dong & 7C BCE & Toilet? & Negative & ND \\
\hline & Jeju/Oedo & 1-4C CE & Pit & Negative & ND \\
\hline & Jeju/Aewol & 14-16C CE & Cemetery & Negative & ND \\
\hline & Seoguipo/Hwasun-ri & $2,000 \mathrm{BP}$ & Pit & Negative & ND \\
\hline & Jeju/Gosan-ri & Neolithic & House & Negative & ND \\
\hline
\end{tabular}

caused by a heavy parasitic infection among the people in the major city of Joseon period.

Sampling at an ancient fortress Hwawangsansung built on the top of a mountain also showed interesting patterns to paleoparasitologists. Actually, in Korean history, there were many fortresses constructed on the mountaintop areas. As these ancient facilities were used as refugees in times of war or rebellion; or were established as political centers in the provinces, they also became highly populated areas at a certain period of ancient times, like major cities of the country $[9,14]$. The presence of ancient eggs in fortress soil strata might therefore have been caused by the overpopulation within the area. In fact, our parasitological examinations clearly exhibited Ascaris, Trichuris, and Taenia eggs in the ancient soil strata samples from the ancient fortress Hwawangsansung area [24] (Table 3). Taken together, by paleoparasitological investigations, we managed to know the glimpses of the patterns about ancient parasitism in the highly populated areas. Briefly, the great number and ubiquity of parasite eggs in the strata soil samples from ancient major city ruins clearly suggested that the parasite infection must have been the major cause of people's diseases, especially among urban populations in history. Serious parasite egg contamination in ancient urban area soils might have been a common phenomenon shared by any of historical major cities worldwide, based on the paleoparasitological studies previously done in each country [25-29]. Of course, we must admit the limitation of this speculation because there are many possibilities concerning higher soil contamination of 
parasite eggs in the samples from ancient major city ruins. More studies on ancient samples are still needed for the hypothesis to be placed upon firm scientific basis.

\section{PLAUSIBLE MECHANISMS OF PARASITE INFECTION AMONG ANCIENT CITY-DWELLERS}

Pioneering studies successfully revealed a serious parasiteegg contamination in the soils from such highly populous areas of the past [5]. Based upon it, it demonstrated the possibility that parasite infection prevalence might have been far higher among city-dwellers in history. Even so, however, its exact reinfection mechanism has remained elusive until recently. In fact, the scientific data based upon simple parasitic examination is not sufficient for answering to this question. Rather, we need much sophisticated way approaching this subject from quite a different angle.

For instance, as to why the several hundred-year-old Joseon strata soils within Old Seoul City were so extensively contaminated by ancient parasite eggs, our research on Joseon documents efficiently raised the possibility that it might have been caused by vegetable growing practices around the highly populated city areas. In order to support the large population of the capital area in the 17th century, the Joseon people must have cultivated almost every corner of the city, maintaining a large-scale vegetable farm within or around Old Seoul City area [2]. To meet the inevitably urgent demand for enormous amounts of fertilizer for growing vegetables, the farmers of Old Seoul City resorted to the purchase of the human waste from so-called 'night-soil men' [2,30]. Night soil, in the centuries prior to industrialization, became the fertilizer of choice in East Asia, especially for vegetable growing, which require larger amount of fertilization than do other crops $[2,31]$.

This use of night-soil fertilizers for vegetable farming might have caused hitherto unexpected health problems for the citydwellers. It is likely that once human waste had been introduced to nearby farmlands, a vicious cycle of parasite infections might have been repeated continuously in Old Seoul City [2]. The inevitable results of the operation of this vicious cycle, not only in Old Seoul City, but also in any of the premodern East Asian cities, could have been increasing rates of parasitic infections among the city-dwellers $[2,21,23,32,33]$. Although a review of extant Joseon records can be instructive to why Old Seoul City people was infected by soil-transmitted parasites so seriously, this hypothesis is not firmly based on scientific evidences. The limitation must be overcome by future studies of paleoparasitology on more ancient samples from archaeological sites in South Korea.

\section{THE FLOODING}

Our parasitological examination of samples from Old Seoul City ruins uncovered another intriguing fact. That is, parasite eggs were not detected exclusively in specific places, public toilets, for example, that once would have included human waste. Rather, they were discovered much more indiscriminately in multiple districts, irrespective of those areas' or sites/original purposes $[21,23]$. Particularly difficult to understand about this was how parasite eggs could have been so widespread in areas such as the open, high-traffic public space of the busiest main street of the capital city [21]. Considering that people would have abstained from defecation in areas of that type, the exact cause of the soil's contamination by parasite eggs remained unclear to us [2].

In this regard, the extant historical records also provided a possible answer once again. We found a number of contemporary descriptions of natural disasters occurring in Old Seoul City during the Joseon period: a repeated rainy-season flooding in most of the areas situated close to streams [2,34-36]. Concerning the likely cause of that flooding, we noted that each hill in the city had been recklessly stripped bare to procure wood for the purposes of home heating during the harsh winter months [2,37]. The land erosion resulting from the hillside deforestation had begun to choke the streams of the capital. The streambeds elevated markedly, making the waterflow sluggish and thereby heightening the risk of flood during the rainy season $[21,32]$.

The areas prone to flooding were widely scattered in Old Seoul City, according to the historical record. These were also the locations of the 2 most likely site-sources of human waste: many public toilets in the Old Seoul City area [2] and the vegetable fields and gardens in and around the city on which human waste was spread as the main ingredient in fertilizer. Therefore, when flooding did occur, it could have conveyed human wastes rapidly and indiscriminately throughout the capital districts [2] (Fig. 1E, F).

In fact, the widespread parasite-egg contamination of soil due to the failure in preventing or controlling flood was not exclusive to Old Seoul City. As another example, we have seen the archaeological ruins of Buyeo, the capital city (538-660 
CE) of the ancient Baekje kingdom. Our parasitological analysis of the area revealed a very wide distribution of ancient parasite eggs, as represented in most of the samples there, irrespective of the original purposes of the given sites [22].

We thus conjecture that the ancient Buyeo city areas prone to flooding might also have been extensively distributed, just as they were in Old Seoul City. It thus evidently caused the spread of parasite-egg-contaminating silts throughout the Baekje kingdom's capital [22]. Corroborating evidence was found in the extant historical record of the Baekje period (Samguksagi), specifically an account of flooding that had oc-

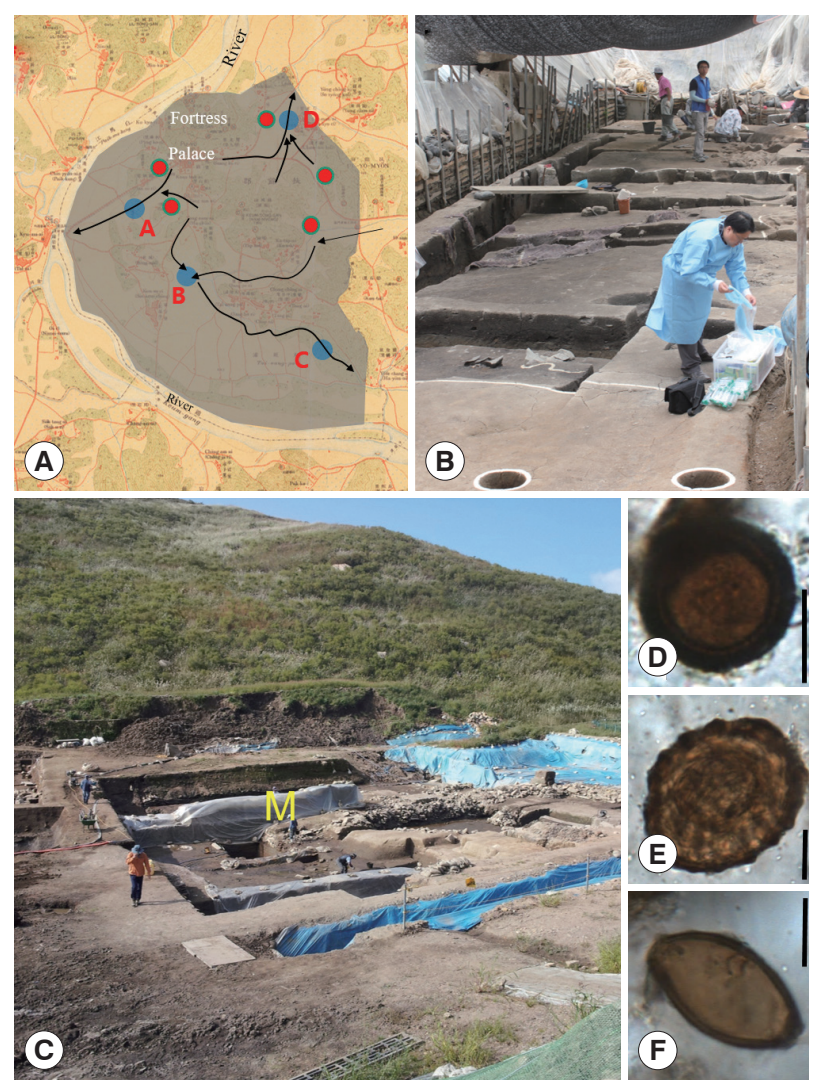

Fig. 2. (A) The map of Buyeo city, the capital of ancient Baekje kingdom (shaded area). Archaeologists assume the ancient watercourses of the streams (indicated by black arrows) running through the Baekje capital. Red dots represent the archaeological sites we found ancient parasite eggs in the geological strata soils. Blue dots indicate the reservoirs arranged for controlling the flooding by Baekje people. Outside of the capital area, we could not find any of ancient parasite eggs in the ancient Baekje territory. (B) Our sampling in Buyeo city. (C) Mountaintop fortress of Silla Dynasty (57 BCE to 935 CE). Ancient parasites were discovered in the ancient moat ruins (M). (D) to (F) Ancient parasite eggs discovered from Hwawangsansung reservoir ruins. (D) Taenia spp., (E) Ascaris lumbricoides, (F) Trichuris trichiura. Bars $=20 \mu \mathrm{m}$. curred in Buyeo in its earliest days as the capital city [22] (Fig 2A, B). Overall, based on historical evidences, it seems that in ancient times, repeated flooding might have caused parasiteegg contamination of city environs much more frequently than scholars have expected.

\section{WATER FACILITIES}

Much like modern-day city planners, ancient-city officialdom concerned themselves with the construction of facilities that could deliver basic life improvements or maintain the prosperity or security of the polity [38]. One of such facility was the moat, basically a water-filled ditch dug around castles, towns, or cities.

In East Asia, as in all other civilizations, moats were constructed from earliest days, chiefly as lines of defense against enemy attack. Archaeologists in this region have made many references to moat ruins in the courses of their investigations of ancient archaeological sites. Moats' unquestioned utility aside, their stagnant water must have incurred serious sanitary problems. For instance, parasitological investigations of an ancient Japanese archaeological site in Yayoi village found the evidence of contamination in the moat by human waste that must have been washed into it by periodic heavy rains [26].

We reported similar findings made in the course of a paleoparasitological investigation of a palace dating to the Silla Dynasty (57 BCE to $935 \mathrm{CE}$ ). In the mud-soil strata of a moat there, we found a plenty of ancient Trichuris eggs [39]. Considering that soil-transmitted parasite eggs generally are shed in human or animal waste, the contents of toilets located somewhere nearby the royal palace might have been drained into the moat at certain times. Thus highly contaminated, the moat almost certainly would have become the source of various infectious diseases among the ancient Silla inhabitants [39].

Moats were not the only parasite-contaminated water facilities in ancient cities. In Korean history, there are multiple cases in which reservoirs were constructed at mountaintop fortresses to provide water to soldiers and civilians resisting invaders [24] (Fig. 2C). In our parasitological study on the reservoir ruins of an ancient Silla fortress Hwawangsansung, we found many Ascaris, Trichuris, and Taenia eggs in soil samples [24] (Fig. 2D-F). Concerning this abundance, we suspected that human or animal waste scattered in and around the fortress was swept via streams into the reservoir, particularly as it was situated at a relatively lower altitude [24]. It seems likely that this reservoir, 
ironically, might have been transformed into a serious sanitary menace to the same patriots it had been constructed to sustain. In a sense, the moats and reservoirs of the ancient cities or fortresses clearly showed the facilities' reverse side of convenience.

\section{CONCLUSION}

With respect to parasite infections in the high-density populations of ancient towns and cities, we have managed to catch certain glimpses of the patterns prevalent therein via paleoparasitological investigations. Our studies on archaeological premodern city or fortress ruins in South Korea have revealed various types of ancient parasite eggs, and usually in large numbers, in representative soil-sediment samples. As to the issue of the great number and ubiquity of parasite eggs in samples from ancient city ruins, parasite infections indeed must have been one of the most common diseases among urban populations in history. Practices that are in hindsight questionable (the use of human-waste-based fertilizer, deforestation, and the unintended consequences of stagnant water, among others), as combined with periodic flooding during the rainy season, had had their effect on higher parasite infection prevalence in pre-modern city with high population density. A plausible mechanism by which the people of Old Seoul City and other major East Asian cities might have suffered from high prevalence of parasite infections could also be constructed in this review.

\section{ACKNOWLEDGMENT}

This work was supported by Basic Science Research Program through the National Research Foundation of Korea (NRF) grant funded by the Ministry of Education, Science and Technology (MEST) (2016R1A2B4015669).

\section{REFERENCES}

1. Larsen CS. Biological changes in human populations with agriculture. Ann Rev Anthropol 1995; 24: 185-213.

2. Kim MJ, Ki HC, Kim S, Chai JY, Seo M, Oh CS, Shin DH. Parasitic infection patterns as correlated with urban-rural recycling of night soils in Korea and other East Asian countries: the archaeological and historical evidence. Korean Studies 2014; 38: 51-74.

3. Wheelwright J. Days of Dysevolution. Discovery 2015, pp 32-39.

4. Barnes E. Diseases and Human Evolution. Albuquerque, USA.
University of New Mexico Press. 2005.

5. Reinhard KJ, Araújo A. Archaeoparasitology. In Pearsall DM ed, Encyclopedia of Archaeology. New York, USA. Academic Press. 2008, pp 494-501.

6. Ruffer MA. Note on the presence of "Bilharzia haematobia" in Egyptian mummies of the twentieth dynasty (1250-1000 BC). Br Med J 1910; 1: 16.

7. Ferreira LF, Araújo A, Confalonieri U. Congresso Brasileiro De Parasitologia, editors. 2. Resumos. Campinas, SP: 1979. Subsidios para a Paleoparasitologia do Brasil I-Parasitos encontrados em coprólitos no município de Unai, Minas Gerais; p 56.

8. Ferreira LF, Reinhard K, Araújo A. Fundamentos da Paleoparasitologia. Rio de Janeiro, Brazil. Editora Fiocruz. 2011. p 484.

9. Seo M, Araujo A, Reinhard K, Chai JY, Shin DH. Paleoparasitological studies on mummies of the Joseon Dynasty, Korea. Korean J Parasitol 2014; 52: 235-242.

10. Le Bailly M, Gonçalves ML, Lefevre C, Roper DC, Pye JW, Araujo A, Bouchet F. Parasitism in Kansas in the 1800s: a glimpse to the past through the analysis of grave sediments from Meadowlark cemetery. Mem Inst Oswaldo Cruz 2006; 101 (suppl 2): 53-56.

11. Le Bailly M, Landolt M, Bouchet F. First World War German soldier intestinal worms: an original study of a trench latrine in France. J Parasitol 2012; 98: 1273-1275.

12. Reinhard KJ, Araújo A, Sianto L, Costello JG, Swope K. Chinese liver flukes in latrine sediments from Wong Nim's Property, San Bernardino, California: archaeoparasitology of the Caltrans District Headquarters. J Parasitol 2008; 94: 300-303.

13. Mitchell PD, Anastasiou E, Syon D. Human intestinal parasites in crusader Acre: evidence for migration with disease in the medieval period. Int J Paleopathol 2011; 1: 132-137

14. Seo M, Oh CS, Chai JY, Lee SJ, Park JB, Lee BH, Park JH, Cho GH, Hong DW, Park, HU, Shin DH. The Influence of differential burial preservation on the recovery of parasite eggs in soil samples from Korean Medieval tombs. J Parasitol 2010; 96: 366-370.

15. Schulz S, Kroeger A. Soil contamination with Ascaris lumbricoides eggs as an indicator of environmental hygiene in urban areas of north-east Brazil. J Trop Med Hyg 1992; 95: 95-103.

16. Uga S, Ono K, Kataoka N, Safriah A, Tantular IS, Dachlan YP, Ranuh IG. Contamination of soil with parasite eggs in Surabaya Indonesia. Southeast Asian J Trop Med Public Health 1995; 26: 730-734.

17. Uga S, Nagnaen W, Chongsuvivatwong V. Contamination of soil with parasite eggs and oocysts in southern Thailand. Southeast Asian J Trop Med Public Health 1997; 28 (suppl 3): 14-17.

18. Chongsuvivatwong V, Uga S, Nagnaen W. Soil contamination and infections by soil-transmitted helminths in an endemic village in southern Thailand. Southeast Asian J Trop Med Public Health 1999; 30: 64-67.

19. Callen EO, Cameron TWM. A prehistoric diet as revealed in coprolites. New Scientist 1960; 8: 35-40.

20. Criscione CD, Anderson JD, Sudimack D, Peng W, Jha B, Williams-Blangero S, Anderson TJ. Disentangling hybridization and host colonization in parasitic roundworms of humans and pigs. 
Proc Biol Sci 2007; 274: 2669-2677.

21. Shin DH, Oh CS, Lee SJ, Chai JY, Kim J, Lee SD, Park JB, Choi IH, Lee HJ, Seo M. Paleo-parasitological study on the soils collected from archaeological sites in old district of Seoul City. J Arch Sci 2011; 38: 3555-3559.

22. Shin DH, Shim SY, Jeong HJ, Kim MJ, Lee MH, Kim KY, Lee IH, Kim G, Chai JY, Oh CS, Seo M. A Paleoparasitological Study on the Capital Area of the Ancient Korean Kingdom. J Parasitol 2015; 101: 458-461.

23. Shin DH, Oh CS, Shin YM, Cho CW, Seo M. The pattern of ancient parasite egg contamination in the private residence, alley, ditch and streambed soils of old Seoul City, the capital of Joseon dynasty. Int J Paleopathol 2013; 3: 208-213.

24. Kim MJ, Seo M, Oh CS, Chai JY, Lee J, Kim GJ, Ma WY, Choi SJ, Reinhard K, Araujo A, Shin DH. Paleoparasitological study on the soil sediment samples from archaeological sites of ancient Silla Kingdom in Korean peninsula. Quart Int 2016; 405: 80-86.

25. Monckton A. Environmental archaeology in Leicestershire. Transactions of the Leicestershire. Arch Hist Soc 1995; 69: 32-41.

26. Matsui A, Kanehara M, Kanehara M. Palaeoparasitology in Japandiscovery of toilet features. Mem Inst Oswaldo Cruz 2003; 98 (suppl 1): 127-136.

27. Fernandes A, Ferreira LF, Gonçalves ML, Bouchet F, Klein $\mathrm{CH}$, Iguchi T, Sianto L, Araujo A. Intestinal parasite analysis in organic sediments collected from a 16th-century Belgian archeological site. Cad Saude Publica 2005; 21: 329-332.

28. da Rocha GC, Harter-Lailheugue S, Le Bailly M, Araújo A, Fer- reira LF, da Serra-Freire NM, Bouchet F. Paleoparasitological remains revealed by seven historic contexts from "Place d'Armes", Namur, Belgium. Mem Inst Oswaldo Cruz 2006; 101 (suppl 2): 43-52.

29. Mitchell PD, Stern E, Tepper Y. Dysentery in the crusader kingdom of Jerusalem: and ELISA analysis of two medieval latrines in the City of Acre (Israel). J Arch Sci 2008; 35: 1849-1853.

30. Nesaki M. The human manure distribution of the Edo Era and the view of raw sewages. Hosei J Human Env 2008; 9: 1-21.

31. Tajima K. The marketing of urban human waste in the early modern Edo/Tokyo Metropolitan area. Env Urbain/Urban Env 2007; 1: 13-30.

32. Kim HJ. The great dredging works on Cheonggye-cheon in the Choson Dynasty. J Korea Water Resources Ass 2004; 37: 22-25.

33. Ki HC, Bae JH, Shin DH. Historical study on factors inducing soil-transmitted helminth infection among people of old Seoul City during Joseon Dynasty. Uisahak (Med Hist) 2013; 22: 89132.

34. Sungjongwon ilgi, King Hyojong, 1650 CE; Year 1, July 18.

35. Sungjongwon ilgi, King Sukjong, 1702 CE, Year 28, July 25.

36. Sungjongwon ilgi, King Yo ngjo, 1748 CE, Year 24, May 9.

37. Sungjongwon ilgi, King Yo ngjo, 1726 CE, Year 2, Dec. 6.

38. Miksic JN. Water, urbanization, and disease in Ancient Indonesia. Archeol Papers Am Anthropol Assoc 2008; 9: 167-184.

39. Shin DH, Oh CS, Chung T, Yi YS, Chai JY, Seo M. Detection of parasite eggs from a moat encircling the royal palace of Silla, the ancient Korean Kingdom. J Arch Sci 2009; 36: 2534-2539. 
